\title{
Determinants in Relocation of Capital Cities
}

\author{
Doris Kokutungisa Ishenda, \\ School of Public Administration, Hohai University, Nanjing China \\ E-mail: Ishenda@yahoo.co.uk
}

Shi Guoqing

School of Public Administration, Hohai University, Nanjing China

Received: Oct. 21, 2019 Accepted: Nov. 13, 2019 Online published: Dec. 5, 2019

doi:10.5296/jpag.v9i4.15983

URL: https://doi.org/10.5296/jpag.v9i4.15983

\begin{abstract}
The capital city is characterized as a multifunctional city that has diplomatic missions, government institutions and economic centers that are so developed that often the capital is chosen as a city of urbanization by the Government. In Indonesia, floods often hit Jakarta and paralyze economic and governmental activities. To overcome the various problems of the capital, one solution that can be considered by a country is to move its capital. In Indonesia, the discourse to move the capital has a long history. This discourse arose against the background of various complex Jakarta problems. Indonesia needs to consider these three factors in the analysis to move its capital, not only the analysis in the country, but also the analysis of the experiences of other countries in the world that have moved its capital. The experience of various countries that have moved their capital cities will provide input and considerations, which could be used as a more appropriate analytical method to examine problems in Indonesia.
\end{abstract}

Keywords: capital city, relocation, Indonesia, Jakarta

\section{Introduction}

A capital city is the center of a country that has the primary status in the government of the country, which is designated by the law. In its role as the center of government, the capital generally functions as the center of political and economic power such that it plays an important role in the life of the nation and state. In many countries, the capital is the largest city in a country where the city reflects a unique style in terms of the economy and culture of the people. Thus, the capital has an important role in showing the character of a country. The capital city is characterized as a multifunctional city that has diplomatic missions, 
government institutions and economic centers that are so developed that often the capital is chosen as a city of urbanization by the Indonesian Government. As part of a country's identity, the capital was built to make it a city that has a main function in government. Most countries in the world, including Indonesia, have capitals at the center of executive, legislative and judicial functions (classic capital). A few other countries separate their executive, legislative and judicial centers to different cities (split capital) such as the Netherlands (Amsterdam and The Hague), South Africa (Pretoria, Bloemfontein, and Cape Town), Bolivia (La Paz and Sucre), The Kingdom of Eswatini (Lobamba and Mbabane), Malaysia (Kuala Lumpur and Putrajaya), and Sri Lanka (Colombo and Sri Jayawardenapura Kotte). Campbell (2004) summarizes the various types of capitals and divides them into six main categories, namely classic capitals, relocated capitals, constructed capitals, federal capitals, split capitals, archipelago capitals, and capitals with unique jurisdictions.

Managing the capital is not easy because it is a major city for social, economic and political activities; hence, mismanagement has the potential of causing various problems. When a city becomes the capital, the city will usually experience significant growth and consequently produce demographic and economic impacts from the accumulated power (Dascher 2000). Demographic and economic impacts that are not matched by good management will cause various urban problems. Problems arising from mismanagement of the capital include economic and political centralization, economic inequality, poor transportation systems, high poverty rates, unemployment and horizontal conflicts. In addition, a country often experiences problems related to natural conditions such as floods and earthquakes. For example, the hurricane that hit Belize City in the country of Belize has caused the country to move its capital from Belize City to Belmopan. The cyclone paralyzed the activities of the Belizean government and even caused damage and loss of important government documents. In Indonesia, floods often hit Jakarta and paralyze economic and governmental activities. To overcome the various problems of the capital, one solution that can be done by a country is to move its capital. Schatz (2003) argues that in theory a well-designed and well-executed capital transfer can provide economic opportunities and government services as a solution to the problem of inequality in other regions. Several post-World War II countries have moved their capital cities for various reasons. There are three common reasons for moving the capital, namely socioeconomic considerations, political considerations, and geographical considerations (Rukmana 2010).

In Indonesia, the discourse to move the capital has a long history. This discourse arose against the background of various complex Jakarta problems. The problem is due to the complex development of Jakarta that is not balanced by good city management so that the Jakarta government continues to be overwhelmed by these problems. The development of Jakarta as the capital has an impact on economic development that is too centralized, leading to the centralization of the national economy. This has led to Jakarta being increasingly crowded with migrants from various regions who hope to improve their economic lives, leading to high urbanization. The large number of population coupled with the high flow of urbanization caused various demographic problems in Jakarta. 
Table 1. Total population of DKI Jakarta in 2010 - 2015 (people)

\begin{tabular}{|l|l|r|r|r|r|r|}
\hline \multirow{2}{*}{\multicolumn{2}{|c|}{ Regency / City }} & \multicolumn{4}{|c|}{ Total population (thousand) } & \multicolumn{2}{c|}{$\begin{array}{c}\text { Population growth rate } \\
\text { per year }\end{array}$} \\
\cline { 3 - 7 } & \multicolumn{1}{|c|}{2010} & 2014 & \multicolumn{2}{l|}{2015} & $2010-2015$ & $2014-2015$ \\
\hline 1 & Kepulauan Seribu & 21414 & 23011 & 23340 & 1,74 & 1,43 \\
\hline 2 & Jakarta Selatan & 2071628 & 2164070 & 2185711 & 1,08 & 1,00 \\
\hline 3 & Jakarta Timur & 2705818 & 2817994 & 2843816 & 1,00 & 0,92 \\
\hline 4 & Jakarta Pusat & 895371 & 910381 & 914182 & 0,42 & 0,42 \\
\hline 5 & Jakarta Barat & 2292997 & 2430410 & 2463560 & 1,45 & 1,36 \\
\hline 6 & Jakarta Utara & 1653178 & 1729444 & 1747315 & 1,11 & 1,03 \\
\hline & DKI Jakarta & $\mathbf{9 6 4 0 ~ 4 0 6}$ & $\mathbf{1 0 ~ 0 7 5 ~ 3 1 0}$ & $\mathbf{1 0 1 7 7 9 2 4}$ & $\mathbf{1 , 0 9}$ & $\mathbf{1 , 0 2}$ \\
\hline
\end{tabular}

Source: DKI Jakarta BPS (2017)

If this continues, the population of Jakarta will become increasingly bloated and further aggravate demographic problems such as congestion which is increasingly rampant due to the increasing number of vehicles, poor ecology, and the threat of declining health levels. Green lands and trees are decreasing because they have been turned into concrete layers for the construction of new houses increasingly causing air pollution in Jakarta. The reduced absorption area and the position of Jakarta, which is below sea level, makes flooding difficult to avoid. In addition to population problems, one of the major problems that afflict Jakarta are traffic jams. The results of a study by the DKI Jakarta Provincial Public Works Department stated that economically, congestion causes an increase in travel time (time inefficiency), transportation costs, serious disruption of transportation of export-import products (logistics in general), a decrease in the level of work productivity, and waste of energy in vain (Indonesia Ministry of Public Work, 2013). Research by the Japan International Corporation Agency in 2004 in Mirlanda (2011) stated that if improvements are not made to the transportation system in Jakarta, it is estimated that Jakarta's traffic will be stuck in 2020 with an estimated economic loss of IDR 28.1 trillion (Indonesia in rupiah) and loss of travel time worth 36.9 trillion. Components of the cost of the loss as above are, among others, in the form of vehicle fuel costs, vehicle operating costs, time lost costs, costs of losing economic potential, delayed transactions, air pollution / pollution costs that cause various respiratory illnesses, psychological stress / severe stress and others.

The Ministry of Public Works in 2010 also examined the discourse on the transfer of capital and summarized the various problems facing Jakarta. 83\% of reservoirs and situ (smaller versions of reservoirs) have been heavily polluted,while the other $17 \%$ are moderately polluted. River water quality does not currently meet physical, chemical and biological quality standards (94\% have been heavily polluted and $6 \%$ are moderately polluted). Similarly, $12 \%$ of ground water has been, heavily polluted, $20 \%$ moderately polluted, $45 \%$ mildly polluted, and only $25 \%$ are in the good category. Meanwhile, the carrying capacity of the environment in Jakarta is at a deficit level. Jakarta's ecological footprint has reached 13.5 million global hectares (gha), its value is far higher than its biocapacity which is 142 thousand gha. Furthermore, from the aspect of the water infrastructure of Jakarta and its 
surroundings, it has experienced a serious crisis. Clean water treatment and distribution capacity is still inadequate, with only $50 \%$ of the population being served, especially with the relatively high leakage rate $(47 \%)$. From the governance aspect, inter-regional cooperation within the framework of the metropolitan area is still not effective. Each region has not been able to work together so that it still requires effective coordination in planning, programming and implementation of development programs. Collective leadership at the metropolitan level is not working as expected, so that Jakarta and its surroundings have not been able to develop properly based on a long-term vision (Indonesia Ministry of Public Work, 2010).

Various problems that befell Jakarta caused it no longer to be considered the capital; thus, it was unable to assume the duties of being the capital as mandated by Law Number 29 of 2007 concerning the capital. Jakarta is considered a failure in its responsibilities in the management of spatial planning, natural resources and the environment, population, settlement control, and transportation. One solution to overcome the Jakarta problem is to move the capital. The idea to move the nation's capital from Jakarta to another city has been widely discussed by both the government and academics. President Susilo Bambang Yudhoyono had discussed moving the country's capital from Jakarta during the national working meeting of all Indonesian Provincial Government Association (APPSI) in Palangkaraya, in early December 2009. In addition, the President had also formed a small team tasked with studying the possibility of moving the capital from Jakarta to another city. Through the release of the Indonesian Cabinet Secretariat, in 2013 the President created an informal team tasked with researching and considering plans to move the capital to another city. Furthermore the President, through a press release at the Grand Emerald Hotel, St. Petersburg, Russia, stated that though the Indonesian economy is strong through economic growth, GDP, and income per capita, on the other hand there hasn't been better solutions to overcome Jakarta's problems. Besides, it was concluded that if there wasn't a right solution to overcome Jakarta's problems with urgent interests involved, it was not wrong for the government to consider building a new government center.

In the history of Indonesia, the discourse of moving the capital is not new. During colonialism, the Dutch East Indies government had planned to move the capital from Jakarta to Bandung in 1906. Then during independence, President Sukarno briefly initiated the transfer of the country's capital to Palangkaraya at the inauguration of Palangkaraya as the Capital of Central Kalimantan Province in 1957. Even President Sukarno visited Palangkaraya twice to assess its potential of becoming the nation's capital. During the New Order period, President Suharto also had the idea of moving the country's capital to Jonggol, West Java through Presidential Decree 1 of 1997 concerning the Coordination of Development of the Jonggol Region as an Independent City. The planned move of the capital to Jonggol did not continue with the fall of the New Order government in May 1998 (Rukmana 2010). The need for analysis to address Jakarta's problems is no longer a choice, but has become an urgent matter. In considering moving the capital, Indonesia cannot only look at domestic issues without reflecting on the experience and influencing factors of the country that has moved its capital. The general reasons for moving the capital are socioeconomic considerations, political considerations, and geographical considerations 
(Rukmana 2010). Indonesia needs to consider these three factors in the analysis to move its capital, not only in the country's context, but also looking at it from a worldwide perspective and considering the experiences of other countries in the world that have moved its capital. The experience of various countries that have moved their capital cities will highlight some input and suggestions on the way forward, which could be used as further appropriate analytical material to examine problems in Indonesia.

\section{Literature Review}

In carrying out its role, the capital has several different types. A city is the center of the executive, legislative and judiciary all at once, and there is a city that is the center of one of these functions. Although most capitals have the most dominant functions in government, not all cities are the same. Hall (2006) divides cities into seven types, namely:

1. Multi-Functional Capitals: Combining all or most of the highest functions of government functions at the national level (London, Paris, Madrid, Stockholm, Moscow, Tokyo).

2. Global Capitals: Special conditions of the first type in which the capital also has a role at the super-national level in politics, commercial (economic), or both (London, Tokyo).

3. Political Capitals: has a function as a central city of government, but does not have a role as an economic city center (The Hague, Bonn, Washington, Ottawa, Canberra, Brasília).

4. Former Capitals: A city that was once the capital (no longer has capital status) but still maintains its historical function (St. Petersburg, Philadelphia, Rio de Janeiro).

5. Ex-Imperial Capitals: Special conditions of the third type, where the city is the former capital of the kingdom back to being the capital of the modern era. The city also has an important function in economic and cultural activities for its former kingdom (London, Madrid, Lisbon, Vienna).

6. Provincial Capitals: Special conditions in federal states. Similar to the third type, a city once had a de facto capital status, but in the modern era it has lost its status. The change in status does not affect their function in the surrounding area (Milan, Turin, Stuttgart, Munich, Montréal, Toronto, Sydney, Melbourne).

7. Super Capitals: Cities that have a role and function as the center of international organizations. This city is just an ordinary city or a city that has a status as a capital (Brussels, Strasbourg, Geneva, Rome, New York).

In addition to the seven types above, Campbell (2004) summarizes the various types of capital and divides them into six main categories. Campbell summarizes by considering the historical aspects that exist in the city. The categories are:

1. Classic Capitals: Jakarta, Bogota, Caracas, London, Madrid, Mexico City).

2. Relocated Capitals: Ankara (from Istanbul 1923, Turkey).

3. From Almaty to Astana 1998, (Kazakhstan), Lilongwe (from Blantyre 1976, Malawi). 
4. Constructed Capitals: Abuja (from Lagos 1991, Nigeria), Brasilia (from Rio de Janeiro 1960, Brazil), Canberra (from Melbourne 1927, Australia), Islamabad (from Karachi 1960, Pakistan).

5. Federal Capitals: Canberra (Australia), Kinshasa (Congo), Moscow (Russia), Ottawa (Canada).

6. Split Capitals: Amsterdam / The Hague (Netherlands), Bloemfontein / Cape Town (South Africa).

8. Archipelago Capitals: Jakarta (on the island of Java, Indonesia), Tokyo (on the island of Honshu, Japan).

9. Capitals with Unique Jurisdictions: Abuja (Federal Capital Territory, Nigeria), Brasilia (Federal District, Brazil), Mexico City (Federal District, Mexico).

Based on the categorization of Hall and Campbell, a country that moves its capital can be categorized as former capitals, relocated capitals, and constructed capitals.

\section{Method}

This study uses secondary data covering a span of twenty years, namely 1990, 2000, and 2010. Secondary data used are the data needed for decision making of a country's transfer including the variable of capital move decisions (move or not), GDP per capita, growth economy, population, population density, area, governmental form (republic or non-republic), territorial form (archipelago or non-archipelago), and type of capital (separated and non-divided). The data was made using the pooled data method before being analyzed using IBM SPSS software. Secondary data used was obtained from various sources such as The World Bank, The World Factbook from The Central Intelligence Agency USA (CIA), Global Finance Data (GFD), United Nations Data (UNdata) and other sources. In addition, a literature study is also carried out from literature books, journals, and related research results.

\subsection{Logit Model Specifications for Factors Affecting Capital Relocation}

The complete model formulation can be denoted in mathematical equation as follows:

$$
\operatorname{Logit}(p i)=\log _{e}\left(\frac{p i}{1-p i}\right)
$$

Testing of model parameters is done to check the model's goodness of fit. The statistical test conducted was using the Odds Ratio statistic, the $\mathrm{G}$ or likelihood ratio test, and the Wald test statistic. The dependent variable used in this study is the response to the removal of the nation's capital. While the independent variables used are GDP per capita (GD), economic growth (EG), area (A), population (P) and population density (PD). This study also uses three dummy in its regression model, namely dummy form of government (D1), dummy of regional form (D2), and dummy type of capital (D3). Data from these variables is secondary data obtained from various sources. 


\section{Results and Discussion}

Since World War II ended, there have been dozens of countries that have relocated their capital cities. The transfer of capital that occurs is done for various reasons, but in general there are three main reasons for the state to relocate its capital, namely socioeconomic considerations, political considerations, and geographical considerations. Relocation of the capital to a new city that is well-designed and well-executed is considered to be a solution to various problems on a regional or national scale. Countries that have relocated their capitals are included in the type of relocated capitals or constructed capitals. Relocated or constructed capitals indicate that the country has relocated the old capital and is building a new capital. Here is a sample image of a country that has relocated its capital.

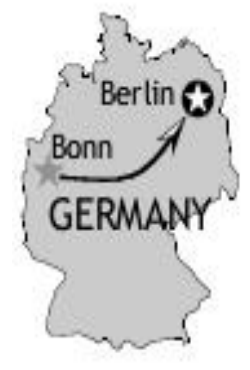

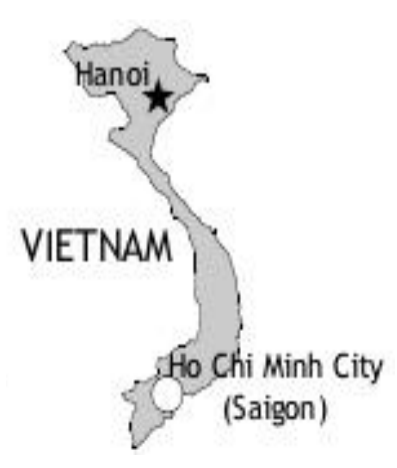

Figure 1. Unification of the capital cities of Germany and Vietnam

Figure 1 shows two countries; Germany and Vietnam, which moved their capital cities after the conflict was over. Germany moved its capital from Bonn to Berlin as a result of the unification of West Germany and East Germany in 1990. Vietnam united its capital to Hanoi after the North Vietnam and South Vietnam conflicts in 1975. Berlin is the capital and also the largest city in Germany, while Vietnam has the capital (Hanoi), which is not the largest city in the country (Ho Chi Minh City which was formerly named Saigon).

Figure 2 shows an example of a country moving its capital from an old city to a new city. It can be seen in the figure that the city that is the new capital is not the largest city in the country. Turkey moved its capital from Istanbul to Ankara in 1923, Brazil moved its capital from Rio De Janeiro to Brasilia in 1960. Malawi moved its capital from Blantyre to Lilongwe in 1975, Nigeria moved its capital from Lagos to Abuja in 1991, and Kazakhstan moved its capital from Almaty went to Astana in 1998. 

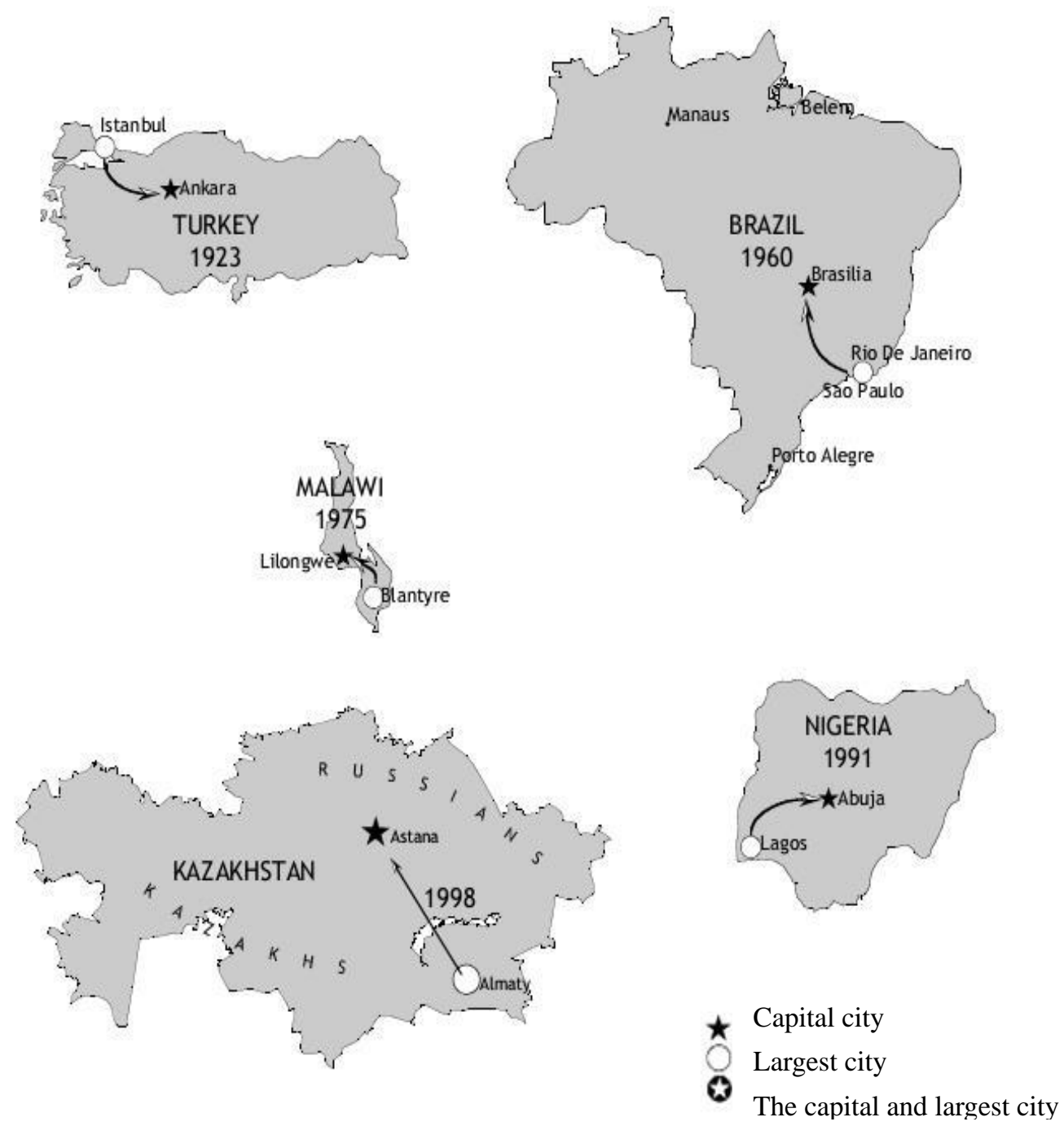

Table 2 is a list of countries that have moved their capital cities after World War II. Table 2 shows that at least thirteen countries have moved their capital cities since World War II ended. The thirteen countries are countries that moved their capital cities so that they are categorized as relocated capitals or constructed capitals. Table 42 does not include countries that have not relocated their capital (only separates executive and legislative cities (split capitals)). Examples of capitals that are categorized as split capitals are Amsterdam - The Hague (The Netherlands) and Kuala Lumpur - Putrajaya (Malaysia). Countries in Table 2 are countries that will be included in the analysis model as countries that have relocated their capital cities. In the first three decades since World War II ended six countries had moved their capital. Then in the next three decades there were seven countries that moved their capital. One of the latest countries to move its capital is Myanmar. This country from Southeast Asia moved its capital from Rangoon to Naypyidaw in 2005. Tanzania is the most recent example of countries that moved their capital city effective 2016 from Dar-es-salaam to Dodoma. 
Table 2. Countries that have relocated their capital cities since World War II

\begin{tabular}{|l|l|l|l|l|}
\hline No. & Country & Old Capital & New Capital & $\begin{array}{c}\text { Year of } \\
\text { Relocation }\end{array}$ \\
\hline 1 & Montenegro & Cetinje & Podgorica & 1946 \\
\hline 2 & Brazil & Rio de Janeiro & Brasilia & 1960 \\
\hline 3 & Pakistan & Rawalpindi & Islamabad & 1967 \\
\hline 4 & Belize & Belize City & Belmopan & 1970 \\
\hline 5 & Guinea Bissau & Boe & Bissau & 1974 \\
\hline 6 & Malawi & Zomba & Lilongwe & 1974 \\
\hline 7 & Filipina & Quezon City & Manila & 1976 \\
\hline 8 & Sri Lanka & Colombo & Sri Jayawardenapura Kotte & 1982 \\
\hline 9 & Ivory Coast & Abidjan & Yamoussoukro & 1983 \\
\hline 10 & Nigeria & Lagos & Abuja & 1991 \\
\hline 11 & Kazakhstan & Almaty & Astana & 1997 \\
\hline 12 & Myanmar & Rangoon & Naypyidaw & 2005 \\
\hline 13 & Tanzania & Dodoma & Dar Es Salaam & 2016 \\
\hline
\end{tabular}

The relationship between capital relocation and GDP per capita can be seen in Table 3 . The table contains the specified years, information on capital relocation and the category of GDP per capita of the country under study. It can be seen that countries that have a high GPD relatively do not relocate their capital when compared to countries that have medium and low GDP.

Table 3. Relationship of GDP per capita with capital transfers

\begin{tabular}{|c|c|c|c|c|c|}
\hline \multirow{2}{*}{ Year } & \multirow{2}{*}{ Description } & \multicolumn{4}{|c|}{ GDP per capita } \\
\cline { 3 - 6 } & & Low & Middle Low & Middle High & High \\
\hline \multirow{3}{*}{1990} & Relocated & 9 & 4 & 0 & 0 \\
\cline { 2 - 6 } & Not Relocated & 5 & 3 & 2 & 3 \\
\hline \multirow{2}{*}{2000} & Relocated & 8 & 5 & 0 & 0 \\
\cline { 2 - 6 } & Not Relocated & 4 & 2 & 4 & 3 \\
\hline \multirow{2}{*}{2010} & Relocated & 4 & 5 & 4 & 0 \\
\cline { 2 - 6 } & Not Relocated & 1 & 4 & 3 & 5 \\
\hline
\end{tabular}

The capital is included in the category of high per capita GPD in 1990, 2000, and 2010. Although there is no category of high per capita GPD, from year to year there is an increase in the number of countries rising from lower GDP per capita to higher GDP per capita . For 
countries that relocate their capital cities, in 1990 there were nine countries in the category of low GDP per capita, then in 2000 it reduced to eight countries, and significantly reduced again to only four countries in 2010. In the category of GDP per capita medium to lower, there was an increase in the number of countries moving their capital cities. This number increased due to a shift in the status of the country from low to medium per capita GDP categories. In the middle to high per capita GDP category, if in 1990 and 2000 none of the countries moved their capital into that category, in 2010 there was an increase of four countries. This shows that countries that relocate their capital cities have experienced an increase in GDP per capita from year to year.

\subsection{Characteristics Based on Economic Growth}

In a World Bank study (2004), economic growth in developing countries was on average higher than in developed countries. In the period 1965-1999, the average growth in low income countries was $4.1 \%$, middle income countries $4.2 \%$, and high income countries $3.2 \%$. This shows that economic growth does not indicate the development status of a country.

The level of economic growth of the countries analyzed in this study has varying values. In 1990 the country with the largest economic growth was Belize with $10.6 \%$ and the country with the smallest economic growth was Kazakhstan with -8.2\%. In 2000 Myanmar became the country with the largest economic growth with $13.7 \%$ and Ivory Coast became the country with the smallest economic growth with $-3.7 \%$. Then in 2010 the country with the lowest economic growth was Portugal with $1.4 \%$ and the highest economic growth was China with $10.4 \%$.

Table 4. Relationship between economic growth and the capital relocation

\begin{tabular}{|c|l|c|c|c|c|}
\hline \multirow{2}{*}{ Year } & \multirow{2}{*}{ Description } & \multicolumn{4}{|c|}{ Economic Growth } \\
\cline { 3 - 6 } & & negative & $1 \%-4 \%$ & $4 \%-7 \%$ & $\geq 7 \%$ \\
\hline \multirow{2}{*}{1990} & Relocated & 4 & 2 & 4 & 3 \\
\cline { 2 - 6 } & Not Relocated & 3 & 4 & 5 & 1 \\
\hline \multirow{2}{*}{2000} & Relocated & 1 & 2 & 6 & 4 \\
\cline { 2 - 6 } & Not Relocated & 1 & 6 & 4 & 2 \\
\hline \multirow{2}{*}{2010} & Relocated & 0 & 5 & 2 & 6 \\
\cline { 2 - 7 } & Not Relocated & 0 & 4 & 6 & 3 \\
\hline
\end{tabular}

The relationship between moving the capital and economic growth can be seen in Table 4. In 1990 the situation between the countries relocating their capital cities and those that did not relocate their capital was relatively balanced. The biggest difference is in the category $1 \%$ $4 \%$ and above $7 \%$ where there are differences between the two countries. In 2000 and 2010 it 
was seen that countries that moved their capital cities had better economic growth where many countries were included in the economic growth category of $4 \%-7 \%$ and above $7 \%$. This shows that countries that move their capital cities have high economic growth. It appears that the higher the economic growth, the country tends to relocate its capital. In general, the world economy is better viewed from declining number of countries with negative economic growth from 1990 - 2010.

\subsection{Characteristics by Area}

The area of the country under study varies in value. The area is calculated based on the land area of a country. Land area is characterized by land that can be inhabited by residents. The country with the smallest area is Montenegro with an area of $13,450 \mathrm{~km} 2$ and the country with the largest area is China with an area of 9,327,480 km2.

Table 5. Relationship of area size with the Capital Relocation

\begin{tabular}{|c|c|c|c|c|}
\hline & \multicolumn{3}{|c|}{ Area } & \\
\cline { 2 - 4 } & $\begin{array}{c}10 \text { thousand- } \\
100 \text { thousand } \\
\mathrm{km}^{2}\end{array}$ & $\begin{array}{c}100 \text { thousand } \\
-1 \text { milion km }\end{array}$ & & \multirow{2}{*}{ Total } \\
\hline Relocated & 5 & 5 & 3 & 13 \\
\hline Not Relocated & 3 & 4 & 6 & 13 \\
\hline Total & 8 & 9 & 9 & 26 \\
\hline
\end{tabular}

Table 5 shows the relationship between the area and the relocation of the capital. Within the range of $10,000-100,000 \mathrm{~km} 2$ there are five countries that move their capital and three countries that did not relocate their capital. In the range of 100,000-1000,000 km2 there are five countries that relocate their capital and four countries that did not relocate their capital, while only three countries relocated their capital in a group that has an area of more than $1000,000 \mathrm{~km} 2$ with six countries that did not relocate their capital.

\subsection{Characteristics Based on Population}

Population density is an important factor analyzed as part of regional economic policy formulation. The countries analyzed in this study have varying population densities. The country with the smallest population density was Mongolia with a population density of 1 person / km2 in 1990, while the country with the highest population density was the Netherlands with a population density of 493 people / km2 in 2010. 
Table 6. Relationship of population density with Capital Relocation

\begin{tabular}{|c|l|c|c|c|c|}
\hline \multirow{2}{*}{ Year } & \multirow{2}{*}{ Description } & \multicolumn{4}{|c|}{ Population } \\
\cline { 3 - 6 } & & $\leq 50$ & $50-100$ & $101-150$ & $\geq 151$ \\
\hline \multirow{2}{*}{1990} & Relocated & 7 & 2 & 2 & 2 \\
\cline { 2 - 6 } & Not Relocated & 5 & 2 & 4 & 2 \\
\hline \multirow{2}{*}{2000} & Relocated & 6 & 2 & 2 & 3 \\
\cline { 2 - 6 } & Not Relocated & 4 & 3 & 4 & 2 \\
\hline \multirow{2}{*}{2010} & Relocated & 4 & 4 & 0 & 5 \\
\cline { 2 - 6 } & Not Relocated & 4 & 3 & 4 & 2 \\
\hline
\end{tabular}

The relationship of population density with the capital relocation can be seen in Table 6 . Countries are more concentrated in the category of countries with population densities below 50 inhabitants / km2. In 1990 and 2000 there was a difference in comparison between countries that relocated their capital and those that did not relocate their capital in the category of population density below 50 people / $\mathrm{km} 2$. If compared to that category, more countries relocate their capital compared to countries that do not relocate their capital. In 2010 there were as many countries in each category as there were for the countries.

Based on the table it can be seen that a country that relocates its capital has a population density that continues to rise compared to a country that does not relocate its capital. Countries that did not relocate their capital cities were even constant in each category in 2000 and 2010. Population density in countries that relocated their capital cities continued to increase until in 2010 there were five countries that relocated their capital cities in the population density category above 150 people / $\mathrm{km} 2$. This shows that the more crowded a country is, the more the country tends to relocate its capital.

\subsection{Characteristics Based on Form of Government}

The form of government analyzed in this study divides the country into two categories namely republic and non-republic. Table 7 presents the distribution of countries based on the form of government. There are eighteen countries that have a republican form of government and the rest are eight countries that have a non-republican form of government.

Table 7. Relationship of forms of government with the Capital Relocation

\begin{tabular}{|c|c|c|c|}
\hline \multirow{2}{*}{} & \multicolumn{2}{|c|}{ Form of government } & \multirow{2}{*}{ Total } \\
\cline { 2 - 3 } & Republic & Non-Republic & 13 \\
\hline Relocated & 9 & 4 & 13 \\
\hline Not Relocated & 9 & 4 & 26 \\
\hline
\end{tabular}

The relationship between the relocation of the capital and the form of government can be 
seen in Table 7. There is each of the nine countries with a republican form of government that relocates and does not relocate its capital. Furthermore, there is each of the four countries with non-republican forms of government that relocated and didn't relocate their capital. The results in the table show that there is a balance of relations between republic and non-republic forms of government. The exact number of countries relocating and not relocating is nine for republican forms of government and four for non-republican forms of government. Based on the table, it can be seen that the countries that relocate their capital have more forms of republican government namely as many as nine countries compared to those who have non-republican government forms which is four countries.

\subsection{Characteristics Based on Territorial Forms}

The territorial forms analyzed in this study divide the countries into two categories, namely archipelagic and non-archipelagic countries. In Table 8 it can be seen that there are five countries with archipelagic territories and 21 countries with non-archipelagic territories. The relationship between relocation of capital and the form of government can be seen in Table 7 . There are three archipelagic countries that move their capital and two archipelagic countries that do not move their capital. Furthermore there are ten non-archipelagic countries that relocate their capital and eleven non-archipelagic countries that do not relocate their capital. The results in Table 8 show that more non-archipelagic countries relocate their capital compared to island nations. The difference in numbers is quite large with ten non-archipelagic nations that have relocated and three island nations that have relocated. This shows that non-archipelagic nations are more likely to relocate capital cities than archipelagic nations.

Table 8. Relationship of territorial forms with Relocation of Capital

\begin{tabular}{|c|c|c|c|}
\hline \multirow{2}{*}{ Definition } & \multicolumn{2}{|c|}{ Territorial forms } & \multirow{2}{*}{ Total } \\
\cline { 2 - 4 } Relocated & Archipelagic & Non-Archipelagic & 13 \\
\hline Not Relocated & 3 & 10 & 13 \\
\hline \multirow{2}{*}{ Total } & 2 & 11 & 26 \\
\hline
\end{tabular}

\subsection{Analysis of Factors That Influence Capital Moving by Using the Logistics Model}

The logistic regression test carried out was a binomial test with two categories of dependent variables, namely relocating capital and not relocating capital with 1 representing relocating capital and 0 otherwise. The explanatory variables used in this model consist of five variables, namely GDP per capita, economic growth, area, population, population density, and three dummy variables, namely the form of government, form of region, and type of capital.

Tables 9 and Table 10 present the results of testing for the logit model obtained, then the interpretation of the values is as follows:

1. Hosmer and Lemeshow Test results shows a p-value of 0.79 , which means the value is greater than the threshold of 5 percent (0.05) hence we reject H0. This means the logit model is fit model and hypothesis testing can be conducted. 
2. The Overall Percentage value of 81.2 means that the logit model is able to classify precisely 81.2 percent.

Table 9. Hosmer and Lemeshow Test Results and Overall Percentage

\begin{tabular}{|l|l|}
\hline Model Testing & Value Obtained \\
\hline Hosmer and Lemeshow Test & 0,79 \\
\hline Overall Percentage & 81,2 \\
\hline
\end{tabular}

Table 10. Factors that influence Capital Relocation

\begin{tabular}{|l|l|l|l|}
\hline Variable & \multicolumn{1}{|c|}{ Coefficient } & \multicolumn{1}{|c|}{ P-value } & \multicolumn{1}{c|}{ Odd Ratio } \\
\hline GDP per capita & $-39,373$ & $0,001^{*}$ & 0,0001 \\
\hline Economic growth & 0,072 & 0,381 & 1,074 \\
\hline Area & 0,074 & $0,021^{*}$ & 1,077 \\
\hline Population & $-0,001$ & $0,067^{* *}$ & 0,999 \\
\hline Density & 0,014 & $0,017^{*}$ & 1,014 \\
\hline Form of government & $-0,849$ & 0,428 & 0,428 \\
\hline Territorial Forms & $-0,383$ & 0,702 & 1,467 \\
\hline Capital Type & 1,566 & $0,040^{*}$ & 4,786 \\
\hline Constant & $-0,136$ & 0,885 & 0,873 \\
\hline
\end{tabular}

Note:

* significant at $5 \%$

** significant at $10 \%$

Based on the outputs in Table 9, the logit model obtained is:

Table 10 shows the results of the analysis using the logistic model. It can be seen in the table that there are four significant variables namely GDP per capita, area, population, and population density. The explanation for each variable will be explained as follows:

\section{GDP per capita}

The logit model results obtained p-value of 0.001 whose value is smaller than the real level of 5 percent (0.05), which means that it is significant at 95 percent confidence level so that it rejects H0. This shows that GDP per capita has a significant effect on capital relocation opportunities.

GDP per capita has a negative coefficient so the higher the GDP, the lower the likelihood of the country to move its capital. This is consistent with the initial hypothesis that GDP per capita is negatively related to capital transfers. The GDP per capita variable has an odd ratio value of 0,0001 , which means that the higher the GDP value, the opportunity not to move the 
capital is 0,0001 times compared to moving the capital.

The conclusion is that the higher the GDP per capita of a country, the country tends not to move its capital, and vice versa. This shows that developed countries with higher GDP per capita usually have better urban planning so that they experience fewer demographic and urban problems.

In addition, many countries move their capital cities with the aim of equal distribution and improvement of the national economy, so countries with low GDP per capita are more likely to move their capital cities in the hope of obtaining economic benefits.

\section{Economic Growth}

The logit model results obtained p-value of 0.381 which value is greater than the real level of 5 percent (0.05), which means accept, H0. This means that economic growth does not significantly affect the chances of moving the capital. The variable of economic growth also has an odd ratio value of 1.074, which means that the higher the value of economic growth, the opportunity not to move the capital is 1.074 times compared to relocating the capital.

This result is different from the initial hypothesis that economic growth is negatively related to capital transfers. Economic growth is positively related to the removal of the capital because economic growth does not always reflect the progress of a country. Economic growth is often influenced by the local and global economic situation of a country that cannot show whether or not a country is progressing. Many developed countries have turned out to have lower economic growth compared to developing countries, and vice versa.

\section{Area}

The area is an important part of the regional governance in the area of urban development. In this research, the logit model p-value obtained was 0.074, the value of which was smaller than the 5 percent real level (0.05), which means that it was significant at the 95 percent confidence level so that it declined H0. This shows that the area has a significant effect on the chances of moving the capital. The area variable is different from the initial hypothesis because it turns out that the area has a positive coefficient so that the greater the area of a country, the country will tend to move its capital.

The wider the area, the higher the various possibilities and policies taken by the government. This shows that the wider the territory of a country, the country will have more choices to overcome demographic and population problems. One option and solution that can be taken by the state is to move its capital. The solution to moving capital requires many choices in spatial terms, and with the wider area of a country the country will have more choices in its spatial policy. The area variable also has an odds ratio of 1.077 , which means that the higher the area, the opportunity to move the capital is 1.077 times compared to not moving the capital.

\section{Total Population}

The population factor is one of the main things that influence the development of a city. The 
increase in population due to natural addition and because of migration influences the policies of a city because it is included in matters affecting demographic problems. The logit model results obtained p-value of 0.067 , which is smaller than the real level of 10 percent (0.1), which means rejecting H0. This means that the population has a significant effect on the chances of moving the capital. The population has a negative coefficient of -0.001 , which is different from the initial hypothesis. The population has a negative coefficient, which means the higher the population; the country tends not to move the capital. This is because the population is not always directly proportional to density. Many urban problems are caused not only by population, but also by a surge in density. Large population does not immediately indicate that the country has urban problems in its capital. The population number variable also has an odd ratio value of 0.999 , which means that the higher the population, the opportunity not to move the capital is 0.999 times compared to moving the capital.

\section{Population Density}

Density that is too high will cause various city problems such as demographic and environmental problems. The logit model results obtained p-value of 0.017 whose value is smaller than the real level of 5 percent (0.05), which means that it is significant at 95 percent confidence level so that it rejects H0. This shows that population density significantly influences the chances of moving the capital. Population density has a positive coefficient so the more densely populated the country will increasingly move its capital. This is consistent with the initial hypothesis that population density has a positive effect on the displacement of the capital.

High density and uncontrolled will cause various problems in the city so that the higher the population density of a country, the country will increasingly move its capital. Problems caused by high population density include declining quality of life, the formation of slums, environmental degradation, high prices, and economic disparity. The population density variable also has an odd ratio value of 1.014, which means that the higher the value of population density, the opportunity to move the capital is 1.014 times compared to not moving the capital.

\section{Form of Government}

The logit model results obtained p-value of 0.428 whose value is greater than the real level of 5 percent (0.05), which means accept H0. This means that the form of government does not significantly affect the chances of moving the capital. The form of government has a negative coefficient so that countries with republican forms of government are more likely to not move their capital than countries with non-republican forms of government. This is consistent with the hypothesis because republic countries usually have democratic government systems. A democratic system is a system of government in which citizens are freer to express their opinions. In a democratic system, if the government cannot convince its people to move its capital, then this will open the opportunity for controversy, rejection, protracted discussion, and the failure of government plans. Historically, the policy of moving the capital has been carried out by strong and ambitious leaders compared to through the power of democracy. 


\section{Territorial Form}

The logit model results obtained p-value of 0.702 , the value of which is greater than the real level of 5 percent $(0.05)$, which means accept H0. This means that the territorial form does not significantly affect the chances of relocating the capital. The territorial form has a negative coefficient so that countries with an archipelagic are less likely to relocate their capital than countries with non-archipelagic. This is different from the initial hypothesis where archipelagic countries are more likely to relocate their capital cities. This tendency arises because the archipelagic state has an area separated by the sea where mobility is relatively more difficult compared to non-archipelagic countries. The fragmented territorial form makes it more difficult for and archipelagic country to relocate its capital because mobilization of human and economic resources will be more difficult and expensive compared to non-archipelagic countries.

\section{Capital Type}

The logit model results obtained p-value of 0.040 which value is greater than 5 percent $(0.05)$, which means accept H0. This means that the type of capital has a significant effect on the opportunity to relocate the capital. The territorial form has a positive coefficient so that the country decides to form its capital with the type of split capitals that is separating its capital will be more successful in relocating its capital. This is consistent with the initial hypothesis that the choice of split capitals has a positive result on the country's opportunity to relocate its capital. This is because splitting the capital into two is more likely when it comes to relocating the capital. Resources that are already centered in the old capital are impossible to abandon so the old capital needs a new role in government so that its resources are not wasted. In addition this can reduce the cost of relocating and creating a new capital. The policy of splitting the capital into more than one will increase the chances of a country's success to relocate its capital.

\subsection{Relationship Between Analysis Results and Conditions in Indonesia}

The results show that the countries that relocate their capital are generally developing countries. These countries have low GDP per capita, large area, large population, and high population density. Indonesia as a developing country has characteristics that are almost similar to this. Indonesia has a lower middle per capita GPD, a very large area with the 15th largest sequence in the world. Indonesia also has a large population of the 4th largest in the world and has a high population density especially in big cities. This shows that Indonesia has a great opportunity to relocate its capital because Indonesia is still a developing country. From the analysis of the factors that increase the opportunity to relocate the capital by using a logistic model, GDP per capita, area, population, population density, and type of capital are factors that increase the country's opportunity to relocate its capital. Higher GDP per capita of a country will reduce the country's chances of relocating its capital. The wider a country's territory will increase the country's chances of moving its capital. In population density, the more crowded a country will increase the country's chances of relocating its capital. Finally, relocating capitals with split capitals will increase the chances of success in relocating the capital. 


\section{Macrothink}

Journal of Public Administration and Governance

ISSN 2161-7104

2019, Vol. 9, No. 4

The current condition of Indonesia still has a low GDP per capita besides that, Indonesia also has a large area that can still be explored and built into new cities. Furthermore Indonesia has a high population density thereby increasing its chances of relocating the capital. Based on this, the removal of the capital of Indonesia is very possible. It is hoped that the relocation of the capital will be a useful policy to overcome regional and national problems. Moving the capital to the right area is expected to overcome the various problems of the old capital and increase the equitable development that has been concentrated in Jakarta. In choosing the type of capital, it would be better if Indonesia uses split type capitals where the capital is separated according to their respective roles. Historically, of the thirteen countries that had moved their capital after World War 2, there were at least six countries that had a split capitals type, which was to separate the capital. These countries are Montenegro (Podgorica and Cetinje), Myanmar (Naypyidaw and Rangoon), Nigeria (Lagos and Abuja), Ivory Coast (Yamoussoukro and Abidjan), Sri Lanka (Colombo and Sri Jayawardenapura Kotte), and Tanzania (Dodoma and Dar Es Salaam). This shows that almost half of the countries that successfully moved their capital cities using split capitals in building new capitals. This separation is done because the existing and developing resources in the old capital such as infrastructure, economic centers, human resources, easy access, and so on will be in vain if not utilized. The separation of the capital is usually divided into cities that have their respective main roles, for example Malaysia which makes Kuala Lumpur as the official capital, the capital of the kingdom, and the legislative center, while Putra Jaya is made as an administrative center and a judicial center (judicative). In addition there is also Sri Lanka, which makes Colombo as a commercial economic center, executive government, and justice, while Sri Jayawardenapura Kotte is used as the center of the legislative body.

Jakarta has become the center of the economy, government, justice, legislature, and has advanced human and infrastructure resources compared to other regions in Indonesia. Jakarta already has everything needed to run a state government. This causes the transfer of all functions of the state government from Jakarta to other regions, which will be very costly because the construction of infrastructure and support in new areas will be very expensive. The cost of relocating the capital of the country will be very large, but on the other hand the loss if the capital remains in Jakarta is also large. Therefore, it would be better if the government was more keen cautious and in its study of relocating the capital. Relocating the capital to a new city will also encourage a more equitable and uneven development direction in Jakarta. It also relays Indonesia from a national economy, which is highly dependent on the rapid economic pace of a handful of big cities that are the center of all activities. This can be seen from Jakarta, which is the center of all economic and government activities, even though this condition accompanied by a contrasting socio-economic life, which will endanger the national economy itself. Gurr in Indonesian Vision 2033 said that this would lead to the potential for social and political explosions that originated in relative deprivation in the form of gaps and dissatisfaction that occurred in various elements of society.

If the government wants to carry out the relocation of the country's capital, Jakarta can be used as an economic center so that the collected resources are not wasted. In addition this can reduce the cost of development in the new capital, which is estimated at 100 trillion in 10 
years of development. Furthermore, a new capital can be built with the role as the center of government where the city is free from various urban and population problems that have been plaguing Jakarta. Besides that, split capitals are also useful in reducing the burden of the new capital in carrying out its role because some of the tasks have been carried out by the old capital.

\section{Conclusions and Recommendations}

\subsection{Conclusion}

Countries that relocate their capital generally are developing countries. Countries that relocated their capital after the Second World War did not have economic characteristics as good as developed countries. These countries have low GDP per capita, large area, large population, and high population density. Based on the results of the analysis of the factors that influence the transfer of the capital, it can be concluded that GDP per capita, area, population, population density, and type of capital are factors that influence the country's opportunity to relocate its capital.

\subsection{Recommendation}

In the study of relocating capitals, the government should pay greater attention to the country's macro economy, especially GDP per capita, as well as long-term projections and plans in regional development. Macroeconomic stability is needed so that the Indonesian economy is more stable. Thus, any policy regarding the removal of the capital in the future will be easier and will not disrupt the country's economic and political stability. Indonesia is still very likely to relocate its capital. In the capital transfer plan, the government should use the split capitals type because this type is more likely to be done. Giving a new role to the old capital will reduce the cost of development and make the resources of the old capital continue to be utilized. On the other hand the burden of the new capital will be releaved if part of its role is maximized by the old capital. The government needs to conduct a demographic policy in the form of regulating the number and distribution of population density so that there is no population buildup in the capital. Moreover, the government must decentralize development so that the economy is more evenly distributed and avoid centralizing economic activity in the capital.

\section{Reference}

[IDRE] Institute for Digital Research and Education. 2013. Annotated SPSS Multinomial Logistic Regression [internet] output. Los Angeles (US): University of California. Available at http://www.ats.ucla.edu/stat/spss/ output / mlogit.htm

[UN] United Nations. (1994). United Nations Convention on the Law of the Sea, Montego Bay (JM): UN.

2013. Statistics Indonesia.

(2013). Statistics Indonesia, Statistical Yearbook of Indonesia

Analisadaily. (2013) Mar. Where will the State Palace Go to? [Internet]. Analisadaily. 
Available at http://www.analisadaily.com

Ardian, B. (2007). City Growth Theories [internet]. Available at http://www.p2kp.org

Campbell, S. (2004). The Enduring Importance of National Capital Cities in the Global Era. URRC, 3(08), 1-32.

Central Statistics Agency (ID). (2013). Statistics of DKI Jakarta 2012. Central Statistics Agency of DKI Jakarta.

Dascher, K. (2000). Are Politics and Geography Related?: Evidence from a Cross-section of Capital Cities. Public Choice, 105, 373-392. https://doi.org/10.1023/A:1005151611464

Firdaus, M. (2008). Application of Selected Quantitative Methods for Management and Business. Bogor (ID): IPB Pr.

Ghozali, I. (2006). Application of Multivariate Analysis with SPSS Program. Semarang (ID): BP UNDIP.

Hall, P. (2006). Seven Types of Capital City. Inside: Gordon P, editor. Planning Twentieth Century Capital Cities. London (GB): Routledge.

Hosmer, D., \& Lemeshow, S. (1989). Applied Logistic Regression. New York (US): John Wiley and Sons Inc.

Indonesia Vision 2033 (ID). (2010). Moving the Capital to Kalimantan: Aisle Out of Various Development Paradoxes, Towards an Orderly Indonesia [internet]. Jakarta (ID): Visi Indonesia 2033. Available at http://www.visi2033.or.id/news_8.htm

Juanda, B. (2009). Econometrics Modeling and Estimation. Bogor (ID): IPB Pr. Juanda, B. 2009. Economic and Business Research Methodology, 2nd Ed. Bogor (ID): IPB Pr.

Kirmanto, D. (2010). Sustainability of Jakarta as the National Capital and City Government Center [internet]. Jakarta (ID): RI Ministry of Public Works. Available at http://www.ructructuring.net/taru/upload/paper / KeynoteMPU_PSIL_221110.pdf

Mankiw, N. G. (2008). Macroeconomics, 6th Ed. Jakarta (ID): Erlangga.

Marangkup, H., \& Ulin, E. (2006). Identification of Suburb Areas and Semarang City Road Network Development Patterns [thesis]. Semarang (ID): Diponegoro University.

Ministry of Public Works Strategic Study Center. (2012). Policy to Overcome Congestion in Jakarta: Towards Strengthening the Role of the Department of Public Works [internet]. Jakarta (ID): RI Ministry of Public Works. Available at http://www.pu.go.id/isustrategis/ view / 24.

Mirlanda, A. M. (2011). Economic Losses Due to Traffic Congestion in the Capital [thesis]. Depok (ID): University of Indonesia.

Novita, F. (2003). Effect of Economic Development in the City of Bandar Lampung on the Development of Coastal Areas [thesis]. Semarang (ID): Diponegoro University. 
Rawat, R. (2005). Capital City Relocation: Global-Local Perspective in The Search for an Alternative Modernity [internet].

Rukmana, D. (2010). Transfer of the National Capital [internet]. Savannah (US): Savannah State University. Available at http://bulletin.penataanruang.net/upload/data_artikel/edisi5i.pdf

Schatz, E. (2003). When Capital Cities Move: The Political Geography of Nation and State Building. Kellogg Institute, 303, 1-29.

Schatz, E. (2004). What Capital Cities Say About State and nation Building. Nationalism and Ethnic Politics, 9, 111-140. https://doi.org/10.1080/13537110390444140

Sihombing, M N. (2012). The Effect of Government Expenditures and Economic Growth on Tax Revenue in Indonesia [thesis]. Bandung (ID): Indonesian Computer University.

Sutikno. (2007). Displacement of the National Capital a Must or a Discourse?. In the Discussion of History, Cities and Social Change in Historical Perspectives; 2007 Apr 11-12; Yogyakarta (ID): Balai Preservation of History and Traditional Value of Yogyakarta.

Tempo.co. (2010). Nov. Andrinof: We Do Not Have a World-Class Capital [internet]. Tempo Media Group. Available at http://www.tempo.co/read/ news / 2010/11/15/173292054 / Andrinof-We-Don't-Have-World-Class-Capital-Capital

Todaro, M. P., \& Smith, S. C. (2003). Economic Development in the Third World, 8th Ed. Jakarta (ID): Erlangga.

Wolfel, R. L. (2002). North to Astana: Nationalistic Motives for the Movement of the Kazakh Capital. Nationalities Papers, 30(3), 485-506. https://doi.org/10.1080/0090599022000011723

Worldbank. (2004). Beyond Economic Growth, An Introduction to Sustainable Development. WBI Learning Resources Series, 2nd Ed. Washington (US): The World Bank.

Yunia, L., \& Rozi, S. (2007). Discourse on Moving Capital in Indonesia (Case Study Opinion of Students, Lecturers, and Employees of IISIP Jakarta). IISIP Jakarta.

[Setkab] RI Cabinet Secretariat. (2013 Oct). Problem of Moving the Capital, Julian: There Is No City Option That Is Considered Eligible [internet]. RI Cabinet Secretariat. Available at http://setkab.go.id/berita-10204-soal-relocating-capital-julian-no-options-city-which-deemedfeasible.html

\section{Copyright Disclaimer}

Copyright for this article is retained by the author(s), with first publication rights granted to the journal.

This is an open-access article distributed under the terms and conditions of the Creative Commons Attribution license (http://creativecommons.org/licenses/by/4.0/). 